\title{
PENINGKATAN MUTU PEMBELAJARAN DENGAN PENDEKATAN PAKEM GURU KELAS V DAN VI MELALUI SUPERVISI KELAS DI SDN. 118267 AEK RASO T.A. 2018/2019
}

\author{
oleh \\ Dewi Siregar \\ dewiganevi@gmail.com
}

SD Negeri 118267 Aek Raso

Desa Torgamba Kec. Torgamba Kabupaten Labuhanbatu Selatan

\begin{abstract}
Abstrak-Transformasi model pembelajaran konvensional (pembelajaran berpusat pada guru) ke pengembangan model yang lebih berpusat pada siswa merupakan salah satu konsekuensi dari kebijakan pemerintah di bidang pendidikan untuk meningkatkan kualitas lulusan di berbagai satuan pendidikan di Indonesia. Oleh karena itu, guru dituntut untuk mampu merancang model pembelajaran yang lebih berpusat pada siswa dengan tetap memperhatikan karakteristik setiap mata pelajaran dan karakteristik siswa agar hasil yang optimal dapat diraih. Secara spesifik, penelitian ini ditujukan untuk meningkatkan pemahaman dan keterampilan guru kelas V dan VI SDN 118267 Aek Raso dalam mengembangkan PAKEM.Penelitian ini merupakan penelitian tindakan sekolah yang dilaksanakan dalam 3 siklus. Hasil penelitian menunjukkan bahwa terdapat peningkatan keterampilan dalam pembuatan RPP guru kelas V dari 84,55 pada siklus 2 menjadi 89,80 pada siklus 3; dan skor RPP guru guru kelas VI meningkat dari 85,44 pada siklus ke 2 menjadi 89,94 pada siklus ke 3. Selain itu, keterampilan dalam penerapan PAKEM semakin meningkat, terutama dalam kaitannya dengan pemilihan metode dan media pembelajaran. Skor pencapaian nilai Pelaksanaan Pembelajaran guru kelas V naik dari 81,57 pada siklus 2 menjadi 89,60 pada siklus 3 dan guru kelas VI dari skor 82,53 pada siklus 2 menjadi 93,55 pada siklus 3. Hal ini menunjukkan adanya peningkatan keterampilan guru dalam melaksanakan KBM dari kurang baik menjadi baik.
\end{abstract}

Kata Kunci: Kualitas pembelajaran, PAKEM

\section{A. PENDAHULUAN}

Pada dasarnya guru harus senantiasa mampu menciptakan atmosfer yang sedemikian rupa dalam proses pembelajaran di kelas. Pembelajaran yang baik itu harus bisa membuat para siswa aktif bertanya dan mengemukakan gagasan selama proses belajar mengajar berlangsung. Proses belajar mengajar seperti ini dikenal dengan istilah pembelajaran yang aktif, kreatif, efektif dan menyenangkan. Hal ini merupakan bagian penting dari pembelajaran dimaksudkan untuk menciptakan pembelajaran yang berkualitas. Pada hakikatnya, belajar merupakan suatu proses aktif dari si pembelajar dalam membangun pengetahuannya, bukan proses pasif yang hanya menerima kucuran ceramah guru tentang pengetahuan. Oleh karena itu, guru memiliki kewajiban untuk menciptakan proses pembelajaran yang membuat pembelajar aktif di kelas.

Apabila pembelajaran tidak memberikan kesempatan kepada siswa untuk berperan aktif maka pembelajaran tersebut bertentangan dengan hakikat belajar. Peran aktif dari siswa sangat penting dalam rangka pembentukan generasi yang kreatif, yang mampu menghasilkan sesuatu untuk kepentingan dirinya dan orang lain. Saat ini, berbagai pendekatan dan model pembelajaran dapat dipahami dan diterapkan 
guru di kelas, dan PAKEM merupakan satu dari model-meodel tersebut. Penerapan model PAKEM siswa didik untuk gemar membaca, belajar dengan sungguh-sungguh, mengerjakan sesuatu pekerjaan dengan sebaik mungkin, berupaya mendapatkan hasil terbaik, bekerjasama dengan sesama teman dan hal-hal positif lainnya.

PAKEM merupakan singkatan dari pembelajaran aktif, kreatif, efektif, dan menyenangkan. Aktif dimaksudkan bahwa dalam proses pembelajaran guru harus menciptakan suasana sedemikian rupa sehingga siswa aktif bertanya, mempertanyakan, dan mengemukakan gagasan. Belajar memang merupakan suatu proses aktif dari si pembelajar dalam membangun pengetahuannya, bukan proses pasif yang hanya menerima kucuranceramah guru tentang pengetahuan. Jika pembelajaran tidak memberikan kesempatan kepada siswa untuk berperan aktif, maka pembelajaran tersebut bertentangan dengan hakikat belajar. Peran aktif dari siswa sangat penting dalam rangka pembentukan generasi yang kreatif, yang mampu menghasilkan sesuatu untuk kepentingan dirinya dan orang lain.

Untuk mengimplementasikan PAKEM dengan baik, guru harus senantiasa kreatif dalam kegiatan pembelajaran di kelas. Dengan kata lain guru harus mampu menciptakan kegiatan belajar yang beragam sehingga memenuhi berbagai tingkat kemampuan siswa. Atmosfer yang menyenangkan merupakan suasana belajarmengajar yang menyenangkan sehingga siswa memusatkan perhatiannya (time on task) tinggi. Hal ini sesuai dengan hasil penelitian yang menyebutkan bahwa tingginya perhatian atau konsentrasi siswa terbukti mampu meningkatkan hasil belajar.

Di sisi lain, pelaksanaan PAKEM di kelas harus senantiasa berada di bawah pengawasan, dalam hal ini kepala sekolah. Pengawasan ini dikenal dengan istilah supervisi. Supervisi merupakan bantuan yang diberikan kepada seluruh guru/staf sekolah untuk mengembangkan sekolah secara maksimal. Pada dasarnya supervisi bukanlah kegiatan inspeksi dari orang yang merasa serbatahu (superior) kepada orang yang dianggap belum tahu sama sekali (inferior). Tapi, supervisi akademik dalam bentuk pembinaan dan bantuan yang diberikan kepada guru/pendidik untuk mengembangkan situasi belajar mengajar agar menjadi lebih baik. Sehingga guru-guru selalu mengadakan perbaikan dalam hal cara mereka mengajarkan suatu mata pelajaran dan meningkatkan efektivitas kerja mereka yang pada akhirnya meningkatkan mutu pendidikan di sekolah tersebut.

Tenaga pengajar memerlukan pendampingan secara berkelanjutan hingga mereka benar-benar mencapai kompetensi yang diharapkan, dan guru perlu diberikan umpan balik dari apa yang telah dilaksanakannya dalam proses pembelajaran. Hal ini dilakukan supaya guru dapat meningkatkan kompetensinya, terutama dalam melaksanakan proses pembelajaran. Akhir dari peningkatan kualitas pembelajaran adalah peningkatan hasil belajar siswa dan peningkatan mutu pendidikan. Permasalahan yang telah diuraikan tersebut menjadi titik tolak peneliti untuk meningkatkan kompetensi guru melalui penelitian tindakan sekolah (PTS) yang berjudul "Peningkatan Mutu Pembelajaran dengan Pendekatan PAKEM Guru Kelas 5, 6 Melalui Supervisi Kelas di SDN. 118267 Aek Raso Kec. Torgamba Kab. Labuhanbatu Selatan".

\section{Kajian Teoritis PAKEM}

PAKEM hadir sebagai salah satu opsi model pembelajaran yang mampu memberi pengaruh signifikan terhadap hasil akhir pembelajaran. Secara garis besar, PAKEM dapat digambarkan sebagai berikut: 
1. Siswa terlibat dalam berbagai kegiatan yang mengembangkan pemahaman dan kemampuan mereka dengan penekanan pada belajar melalui berbuat.

2. Guru menggunakan berbagai alat bantu dan berbagai cara untuk membangkitkan semangat, termasuk menggunakan lingkungan sebangai sumber belajar untuk menjadikan pembelajaran menarik, menyenangkan, dan cocok bagi siswa.

3. Guru mengatir kelas dengan memajang buku-buku dan bahan belajar yang lebih menarik dan menyediakan "pojok baca".

4. Guru menerapkan cara mengajar yang lebih kooperatif dan interaktif, termasuk cara belajar kelompok.

5. Guru mendorong siswa untuk menemukan caranyan sendiri dalam pemecahan suatu masalah, untuk mengungkapkan gagasannya, dan melibatkan siswa dalam menciptakan lingkungan sekolahnya.

\section{Supervisi Akademik}

Supervisi Akademik merupakan serangkaian kegiatan membantu guru mengembangkan kemampuannya mengelola proses pembelajaran untuk mencapai tujuan pembelajaran (Daresh, 1989, Glickman, et al; 2007). Supervisi akademik tidak terlepas dari penilaian kinerja guru dalam mengelola pembelajaran. Sergiovanni

(1987) menegaskan bahwa refleksi praktis penilaian kinerja guru dalam supervisi akademik adalah melihat kondisi nyata kinerja guru untuk menjawab pertanyaan-pertanyaan, misalnya apa yang sebenarnya terjadi di dalam kelas?, apa yang sebenarnya dilakukan oleh guru dan siswa di dalam kelas?, aktivitas-aktivitas mana dari keseluruhan aktivitas di dalam kelas itu yang bermakna bagi guru dan murid?, apa yang telah dilakukan oleh guru dalam mencapai tujuan akademik?, apa kelebihan dan kekurangan guru dan bagaimana cara mengembangkannya?.
Beragamnya jawaban terhadap pertanyaan-pertanyaan di atas akan membantu kita dalam memahami dan memetakan kemampuan guru dalam mengelola pembelajaran. Namun satu hal yang perlu ditegaskan di sini, bahwa setelah melakukan penilaian kinerja bukan berarti pelaksanaan supervisi akademik juga selesai, melainkan harus dilanjutkan dengan tindak lanjutnya berupa pembuatan program supervisi akademik dan melaksanakannya dengan sebaik-baiknya. Sedangkan tujuan supervisi akademik adalah:

a. Membantu guru mengembangkan kompetensinya,

b. Mengembangkan kurikulum, dan

c. Mengembangkan kelompok kerja guru, dan membimbing penelitian tindakan kelas (PTK)(Glickman, et al; 2007, Sergiovanni, 1987).

Sebelumsupervisi akademik dilaksanakan, hal-hal yang harus dilakukan oleh seorang pengawas atau kepala sekolah adalah sebagai berikut:

a. Buatlah kesepakatan kapan akan dilakukan supervisi kelas dengan guru yang bersangkutan.

b. Diskusikan materi pelajaran apa yang akan diajarkan pada saat supervisi kelas.

c. Bantulah dalam membuat persiapan mengajar dengan memberikan masukanmasukan yanglebih baik.

d. Yakinkan pada guru yang bersangkutan bahwa kedatangan anda (supervisor) bukan akan menilai atau mengawasi namun anda datang akan memberikan bantuan teknis yang diperlukan oleh guru.

e. Buatlah kesepakatan untuk membagi peran antara anda (supervisor) dengan guru.

Pada tahap pelaksanaan supervisi kelas, hal-hal yang harus dilakukan oleh seorang pengawas atau kepala sekolah adalah sebagai berikut:

a. Datanglah pagi sebelum guru masuk di dalam kelas untuk melakukan "kontrak" ulang tentang: langkah-langkah 
pembelajaran yang akan dilakukan, peran masing-masing yang akan dilakukan, dan pengorganisasian waktu.

b. Masuklah ke dalam kelas bersama-sama dengan guru yang bersangkutan. Kalau supervisor masuk ke dalam kelas belakangan maka akan menganggu konsentrasi anak pada saat proses pembelajaran, dan juga mungkin menimbulkan rasa takut.

c. Mintalah guru yang bersangkutan untuk memperkenalkan diri anda (jika belum kenal) bahwa anda datang di kelas tersebut akan membantu dalam proses pembelajaran agar tidak menimbulkan rasa penasaran bagi anak.

d. Sambil memerankan peran anda dalam proses pembelajaran tersebut, jangan lupa tetap membuat catatan-catatan kecil tentang kelebihan-kelebihan maupun kekurangan-kekurangan yang terjadi selama proses pembelajaran.

e. Jangan sekali-sekali mengambil alih peran guru untuk anda kuasai.

Pada tahap setelah supervisi kelas, hal-hal yang harus dilakukan oleh seorang pengawas atau kepala sekolah adalah dengan melakukan diskusi bersama guru dengan mematuhi 5 langkah berikut:

a. Tunjukkan sikap menghargai (tuliskan komentar anda dibawah ini.

Misalkan: Saya suka dengan kegiatan praktis yang bapak/Ibu lakukan tadi. Siswa benar-benar terlibat dalam kegiatan.

b. Tanyakan refleksi diri yang penting (tuliskan tanggapan guru tersebut dibawah ini).

Misalkan: Bagaimana perasaan anda selama proses pembelajaran tadi? Apakah anda sudah puas?

c. Masihkah ada kekurangan yang anda lakukan selama proses pembelajaran tadi, dibagian mana saja?

d. Tanyakan peningkatan yang ingin dilakukan oleh guru tersebut (tulis tanggapan yang diberikan oleh guru tersebut) misalnya: Hal apakah yang anda ingin lakukan secara berbeda bila anda melakukan pelajaran itu kembali? Mengapa? Bagaimana cara anda meningkatkan

keaktifan/kreativitas/keefektifan/ kesenangan dari pelajaran tersebut?

e. Berikan saran atau arahkan diskusi ke masalah lain yang belum disebutkan yang mungkin masih bisa ditingkatkan (tuliskan saran anda dibawah) misalnya: kelompok yang dipojok tampaknya tidak belajar banyak? Apa yang bisa anda lakukan untuk membantu mereka? Apakah menurut anda alat bantu belajar anda banyak membantu? Bagaimanakah cara meningkatkannya?

f. Rencana tindak lanjut (tuliskan langkahlangkah selanjutnya yang diputuskan bersama) Misalkan: Apa yang perlu Bapak/Ibu lakukan selanjutnya agar pembelajaran yang akan dilakukan besok lebih baik?

Dengan menerapkan teknik-teknik di atas diharapkan kegiatan supervisi kelas dikemudian hari dapat lebih diterima oleh guru sebagai hal yang sangatlah wajar atau bahkan merupakan hal yang dinantinantikan oleh para guru.

\section{B. METODE PENELITIAN}

PTS merupakan penelitian yang diproyeksikan untuk mendapatkan temuan yang sistematis oleh kepala sekolah/madrasah untuk memecahkan masalah pengelolaan sekolah. Ruang lingkup PTS mengacu pada Permendiknas Nomor 19 Tahun 2007 tentang Pengelolaan Sekolah/madrasah yang meliputi:

Perencanaan program sekolah/madrasah, (2) pelaksanaan program sekolah/madrasah, (3) pengawasan/evaluasi sekolah, kepemimpinan, dan (5) sistem informasimanajemen sekolah. Manfaat PTS bagi kepala sekolah/madrasah /madrasah secara umum adalah untuk memecahkan 
permasalahan pengelolaan yang terjadi di sekolah yang menjadi tanggung jawab kepala sekolah/madrasah. Ciri PTS yang paling utama adalah melakukan tindakan di samping 15 ciri lainnya.

Langkah-langkah PTS meliputi perencanaan, pelaksanaan, pengamatan, dan refleksi. Penelitian ini merupakan penelitian tindakan sekolah yang dilaksanakan dalam 2 siklus. Siklus tersebut tergambar dalam bagan berikut:

Adapun pokok-pokok rencana kegiatan tergambar dalam tabel di bawah ini:

\begin{tabular}{|c|c|c|}
\hline Putaran & Tahapan & Kegiatan \\
\hline \multirow{4}{*}{ Siklus 1} & Perencanaan & $\begin{array}{l}\text { Masalah : rendahnya kualitas pembelajaran, } 70 \% \text { guru belum } \\
\text { menggunakan inovasi pembelajaran Alterna tif Tindakan: } \\
\text { 1. Mengadakan Supervisi Bersa habat } \\
\text { 2. Mengadakan Refleksi Bersama Guru }\end{array}$ \\
\hline & Tindakan & $\begin{array}{l}\text { Menerapkan tindakan supervisi kelas ( supervisi pembelajaran ) } \\
\text { yang bersahabat sehingga guru yang di supervisi tidak merasa } \\
\text { canggung/ takut }\end{array}$ \\
\hline & Pengamatan & $\begin{array}{l}\text { 1. Melakukan observasi kelas dengan menggunakan format } \\
\text { supervisi } \\
\text { 2. Melakukan pengamatan hasil supervisi dengan menggunakan } \\
\text { format hasil supervisi }\end{array}$ \\
\hline & Refleksi & $\begin{array}{l}\text { 1. Melakukan evaluasi tindakan yang telah dilakukan yang } \\
\text { meliputi evaluasi mutu, jumlah dan waktu dari setiap macam } \\
\text { tindakan. } \\
\text { 2. Melakukan pertemuan untuk membahas hasil evaluasi } \\
\text { tentang skenario, dll. } \\
\text { 3. Memperbaiki pelaksanaan tindakan sesuai hasil evaluasi, } \\
\text { untuk digunakan pada siklus berikutnya } \\
\text { 4. Evaluasi tindakan I }\end{array}$ \\
\hline \multirow{4}{*}{ Siklus 2} & Perencanaan & $\begin{array}{l}\text { 1. Perencanaan tindakan siklus } 2 \text { berdasarkan hasil analisis dan } \\
\text { refleksi siklus } 1 \\
\text { 2. Penyempurnaan rencana tindakan siklus } 2\end{array}$ \\
\hline & Tindakan & $\begin{array}{l}\text { Menerapkan tindakan supervisi lelas (supervisi } \\
\text { pembelajaran) yang bersahabat sehingga guru yang di } \\
\text { supervisi tidak merasa canggung/ takut dengan beberapa } \\
\text { penyempurnaan agar hasil yang diharapkan lebih baik dari } \\
\text { siklus sebelumnya }\end{array}$ \\
\hline & Pengamatan & Mengumpulkan data siklus 2 \\
\hline & Refleksi & $\begin{array}{l}\text { Mengevaluasi hasil tindakan siklus } 2 \text { Menentukan langkah } \\
\text { selanjutnya } \\
\text { 1. berhasil-menyusun laporan } \\
\text { 2. Merancang siklus } 3\end{array}$ \\
\hline
\end{tabular}

Tabel 1. Rencana Tindakan PTS

Untuk menentukan keberhasilan tindakan dalam PTS ini perlu dibuat indicatorindikator keberhasilan PTS. Adapun indicator keberhasilan tindakan dalam PTS ini adalah sebagai berikut:

\begin{tabular}{|c|c|c|}
\hline No. & $\begin{array}{l}\text { Indikator Keberhasilan } \\
\text { PTS }\end{array}$ & $\begin{array}{l}\text { Rincian Sub Indikator: } \\
\text { Guru yang kualitas ded likasinya meningkat ( } 80 \%)\end{array}$ \\
\hline 1 & $\begin{array}{l}\text { Semakin meningka tnya } \\
\text { kedisiplinan guru }\end{array}$ & $\begin{array}{l}\text { 1. Datang ke kelas tepat waktu } \\
\text { 2. Membuat persiapan mengajar } \\
\text { 3. Menggunakan waktu secara efektif, efisien untuk } \\
\text { mengajar } \\
\text { 4. Guru selalu hadir di kelas }\end{array}$ \\
\hline 2 & $\begin{array}{l}\text { Semakin berkualitasnya } \\
\text { pembelajaran yang dilakukan }\end{array}$ & $\begin{array}{l}\text { 1. Perangkat pembelajaran yang dipersiapkan guru } \\
\text { lengkap } \\
\text { 2. Guru menggunakan media/alat peraga } \\
\text { 3. Guru menggunakan metode/model pembelajaran } \\
\text { yang up to date } \\
\text { 4. Terciptanya suasana PAKEM } \\
\text { 5. Siswa tidak mengantukbermain sendiri }\end{array}$ \\
\hline
\end{tabular}

\section{HASIL DAN PEMBAHASAN}

Teknik pengumpulan data dalam penelitian ini diperoleh melalui observasi dan catatan data lapangan, wawancara, dan catatan hasil refleksi/diskusi yang dilakukan oleh peneliti dan mitra peneliti. Penentuan tekhnik tersebut didasarkan ketersediaan sarana dan prasarana dan kemampuan yang dimiliki peneliti dan mitra peneliti. Uraian lebih lanjut mengenai teknik - teknik pengumpulan data tersebut adalah sebagai berikut:

a. Observasi dan catatan data lapangan

Kegiatan ini dilakukan oleh pengamat yang dalam hal ini adalah kepala sekolah. Bentuk kegiatan observasi yang dilakukan dalam PTS ini menggunakan model observasi terbuka. Adapun yang dimaksud observasi terbuka adalah apabila pengamat atau observer melakukan pengamatan dengan mencatatkan segala sesuatu yang terjadi di kelas.Hasil pengamatan dari peneliti selanjutnya dijadikan catatan data lapangan. Hal ini sesuai dengan pendapat Prof. Dr. Rochiati Wiriaatmaja (2005:125) yang menyatakan: "Sumber informasi yang sangat penting dalam penelitian ini (PTS) adalah catatan lapangan (fildnotes) yang dibuat oleh peneliti/mitra peneliti yang melakukan pengamatan atau observasi.

b. Catatan hasil refleksi

Adapun yang dimaksud catatan hasil refleksi adalah catatan yang diperoleh dari hasil refleksi yang dilakukan dengan melalui kegiatan diskusi antara peneliti dan mitra peneliti. Hasil refleksi ini selain dijadikan bahan dalam penyusunan rencana tindakan selanjutnya juga dapat digunakan sebagai sarana untuk mengetahui telah telah tercapai tidaknya tujuan kegiatan peneliti ini.Sesuai dengan teknik pengumpulan data yang disebutkan di atas, instrumen penelitian 
yang digunakan dalam PTS ini adalah Instrumen Pengamatan.

Berikut peneliti uraikan pembahasan data penelitian siklus demi siklus penelitian:

\section{Pembahasan Data Siklus 1}

Tujuan yang ingin dicapai dalam PTS ini adalah; a) Meningkatkan pemahaman Guru SDN 118267 Aek Raso dalam mengembangkan PAKEM; dan b) Meningkatkan keterampilan Guru SDN 118267 Aek Raso dalam mengembangkan PAKEM. Hasil analisis siklus 1 menunjukkan bahwa:

a. Dilihat dari aspek perencanaan pelaksanaan pembelajaran yang disusun guru tampak bahwa pada siklus 1 RPP dengan pendekatan PAKEM masih kurang. Ini terlihat masih kurangnya keterampilan guru dalam menentukan atau memilih metode dan media yang variatif dan dapat merangsang aktivitas siswa. Data hasil penilaian RPP pada siklus 1 menunjukkan bahwa pencapaian skor nilai RPP Kelas V memperoleh skor 75,78; dan RPP Kelas VI memperoleh skor 76,08. Dengan demikian dua RPP kelas V dan VI dalam kategori baik namun belum mencapai indikator keberhasilan yang penulis tetapkan yaitu 80.

b. Dilihat dari aspek pelaksanaan pembelajaran, berdasarkan data hasil observasi pelaksanaan KBM menunjukkan pencapaian nilai pelaksanaan pembelajaran guru kelas $\mathrm{V}$ memperoleh skor 67,80 ; dan guru kelas VI memperoleh skor 68,90.

\section{Pembahasan Data Siklus 2}

Berdasarkan hasil refleksi pada siklus 1, pada siklus 2 ini PTS lebih memfokuskan pada peningkatan keterampilan guru dalam penerapan PAKEM, terutama dalam penggunaan metode dan media pembelajaran yang mempu meningkatkan keaktifan siswa dalam kegiatan pembelajaran. Hasil analisis siklus 2 menunjukkan bahwa:

a. Dilihat dari segi guru, tampak pada siklus 2 ini kemampuan guru dalam menyususn RPP dengan pendekatan PAKEM sudah mulai mengalami peningkatan terutama dalam kaitannya dengan pemilihan dan penggunaan metode pembelajaran. Data hasil penilaian RPP pada siklus 2 menunjukkan bahwa pencapaian skor nilai RPP kelas $\mathrm{V}$ memperoleh skor 84,55; dan RPP kelas VI memperoleh skor 85,44 . Dengan demikian dua RPP kelas V dan VI dalam kategori baik dan telah mencapai indikator yang ditetapkan yaitu 80.

b. Berdasarkan data hasil observasi pelaksanaan KBM pada siklus 2 menunjukkan pencapaian nilai pelaksanaan pembelajaran guru kelas guru kelas V memperoleh skor 81,57; dan guru kelas VI memperoleh skor 82,53.

Dengan demikian dalam pelaksanaan pembelajaran dua orang yaitu guru kelas V dan guru kelas VI telah mencapai indikator keberhasilan. Oleh karena itu, kegiatan yang masih perlu mendapat perhatian khusus dalam PTS ini pada siklus berikutnya adalah peningkatan keterampilan guru dalam kaitannya dengan pemilihan media pembelajaran yang sesuai dengan pendekatan PAKEM seperti kasus, cerita, film/video, foto (analisis kasus) dan sebagainya disesuaikan dengan konteks materi yang diajarkan.

\section{Pembahasan Data Siklus 3}

Hasil analisis data menunjukkan adanya peningkatan pencapaian nilai atau skor yang cukup baik dan signifikan. Hasil pembahasan dan analisis data pada siklus 3 adalah:

a. Adanya peningkatan keterampilan dalam pembuatan rencana pembelajaran. Skor pencapaian nilai RPP guru kelas V dari 84,55 pada siklus 2 menjadi 89,80 pada siklus 3; dan skor RPP guru guru kelas VI 
meningkat dari 85,44 pada siklus ke 2 menjadi 89,94pada siklus ke 3 .

b. Keterampilan tentang penerapan PAKEM semakin meningkat, terutama dalam kaitannya dengan pemilihan metode dan media pembelajaran. Skor pencapaian nilai Pelaksanaan Pembelajaran guru kelas V naik dari 81,57 pada siklus 2 menjadi 89,60 pada siklus 3 dan guru kelas 6 dari skor 82,53 pada siklus 2 menjadi 93,55 pada siklus 3. Hal ini menunjukkan adanya peningkatan keterampilan guru dalam melaksanakan KBM dari kurang baik menjadi baik.

Berdasarkan hasil refleksi siklus 1, 2, dan 3 yang mencoba mengungkapkan keberhasilan maupun ketidakberhasilan kegiatan bimbingan yang dilakukan kepala sekolah terhadap guru-guru kelas $\mathrm{V}$ dan VI SDN. 118267 Aek Raso dalam penerapan pendekatan PAKEM dapat disimpulkan bahwa pemahaman dan keterampilan guruguru SDN 118267 Aek Raso tentang PAKEM mulai meningkat.

\section{KESIMPULAN DAN SARAN}

Berdasarkan hasil pelaksanaan

Penelitian Tindakan Sekolah (PTS) mengenai penerapan pendekatan pembelajaran Aktif, Kreatuf, Efektif, dan Menyenangkan (PAKEM) langsung selama 3 siklus penelitian dpat disimpulkan:

a. Kegiatan bimbingan penerapan PAKEM bagi guru kelas V dan VI SDN 118267 Aek Raso telah terlaksana dengan baik dan memberi kontribusi terhadap peningkatan pemahaman dan keterampilan guru tentang penerapan pendakatan PAKEM dalam kegiatan pembelajaran.

b. Hasil analisis menunjukkan bahwa peningkatan pemahaman dan keterampilan guru tentang penerapan PAKEM dalam kegiatan pembelajaran berimplikasi pada peningkatan partisipasi atau keaktifan siswa serta terhadap keterlaksanaan nilai hasil belajar siswa. c. Berdasarkan hasil refleksi, kegiatan PTS tentang Upaya Meningkatkan Kualitas Pembelajaran Dengan Pendekatan PAKEM Guru Kelas V dan VI Melalui Supervisi Kelas di SDN 118267 Aek Raso Kecamatan Torgamba Kabupaten Labuhanbatu Selatan Semester 1 Tahun 2018/2019 mencapai tujuan yang diharapkan yakni : (1) Meningkatkan pemahaman Guru SDN 118267 Aek Raso dalam mengembangkan PAKEM; (2) Meningkatkan keterampilan Guru SDN 118267 Aek Raso dalam mengembangkan PAKEM.

Adapun saran yang dapat penulis sampaikan adalah:

a. Penerapan pendekatan pembelajaran aktif, kreatif, efektif, dan menyenangkan (PAKEM) perlu terus ditingkatkan mengingat cukup signifikan dampak positif penerapannya terhadap peningkatan proses dan hasil belajar.

b. Guru-guru harus dapat mengenali dan menggunakan berbagai metode, stretegi dan/atau model pembelajaran; sehingga mempunyai banyak pilihan untuk dapat menerapkan pendekatan PAKEM dalam kegiatan pembelajaran.

c. Selain keterampilan memilih model pembelajaran, guru yang profesional juga hendaknya dapat memilih media yang tepat untuk menyampaikan materi pembelajaran. Oleh karena itu, guru juga diituntut memiliki kreatifitas dan keterampilan memilih media pembelajaran yang tepat.

\section{DAFTAR PUSTAKA}

Bahan Workshop KTSP. 2007. Pengembangan Bahan Ajar dan Media. Depdiknas.

Bobbi De Porte \& Mike Hernacki. 2000. Qunatum Learning Membiasakan Belajar Nyaman dan Menyenangkan. Kaifa: Bandung. 
Bahasa Indonesia Prima, Vol 2. No. 2. 2020

e-ISSN: 2684-6780

Danial, Endang AR, Dr. H. M.Pd. 2003. Penelitian Tindakan Kelas. Directorat PLP, Dirjendikdasmen, Depdiknas: Jakarta 118.

Depdiknas. 2003. Pendekatan Konstektual (Constextual Teaching and Learning). Direktorat Pendidikan Dasar dan Menengah, Direktorat Pendidikan Lanjutan Pertama: Jakarta.

Depdiknas. 2005. Paket Pelatihan 1 Peningkatan Mutu Pendidikan Dasar melalui Manajemen Berbasis Sekolah, Peran Serta Masyarakat, Pembelajaran Aktif, Kreatif, Efektif, dan Menyenangkan. Depdiknas: Jakarta.

Depdiknas. 2007. Evaluasi Program Supervisi Pendidikan, Peningkatan Mutu Pendidik Dan Tenaga Kependidikan Departemen Pendidikan Nasional: Jakarta.

Depdiknas. 2010. Menilai Kinerja Guru. Depdiknas: Jakarta.

Depdiknas, 2011. Penilaian Tindakan Sekolah, Suplemen Materi
Pelatihan Penguatan Kemampuan Kepala Sekolah, Pengembangan Sumber Daya Manusia Pendidikan dan Penjaminan Mutu Pendidikan: Jakarta.

Hasibuan dan Moedjino. 1996. Proses Pembelajaran. Remadja Karya: Bandung.

Hidayat, Kosadi, dkk. 1987. Strategi Pembelajaran Bahasa Indonesia. Bina Cipta: Bandung.

Indonesia. 2005. Undang - Undang Republik Indonesia Nomor 14 Tahun 2005 Tentang Guru dan Dosen.

Sudirman, dkk. 1987. Ilmu Pendidikan. Bandung: Remadja Karya CV. Sudjana. (1992) Metode Statistik. Tarsito: Bandung.

Suhardjono, A. Azis Hoesein, dkk. 1995. Pedoman penyusunan KTI di Bidang Pendidikan dan Angka Kredit Pengembangan Profesi Guru. Digutensis. Diknas: Jakarta.

Suriasumantri, Jujun S. 1999. Filsafat Ilmu Sebuah Pengantar Populer. Pustaka Sinar Harapan: Jakarta. 